\title{
ESPECTROS VIRTUAIS: \\ A construção de corpos-sígnicos em comunidades virtuais de relacionamento
}

\author{
Cíntia Dal Bello ${ }^{1}$
}

\begin{abstract}
Resumo: Este artigo tem por objetivo refletir sobre a questão da identidade em comunidades virtuais de relacionamento - sua construção simbólica como referência à subjetividade do indivíduo e sua relação com a alteridade em um ambiente de alta visibilidade, a partir da constatação de que as redes telemáticas compõem novos processos de subjetivação e o cyberspace propicia novas formas de experimentar as dimensões de ser, estar e relacionar-se. Para tanto, propõe a análise do Orkut como espaço discursivo de enunciação do "eu" onde diversos processos sígnicos são mobilizados na constituição de um espaço de fala a partir do qual o indivíduo possa ser reconhecido e reconhecer a si mesmo como sujeito, dando concretude à sua subjetividade no ciberespaço.

Palavras-chave: Cibercultura; identidade; visibilidade mediática.
\end{abstract}

\begin{abstract}
The aim of this article is to think over the issue of identity in relationship virtual communities - its symbolic constructions as reference to the subjectivity of a person and its relation with others in an atmosphere of high visibility, from testifying that the telecommunication and computer networks compound new processes of subjectiveness and the cyberspace proposes new ways of trying the dimensions of being and relating themselves. For this reason, it proposes an Orkut analysis as a matter of "I" in which several signical processes are gotten in constituting a gap of a speech when the subject can be recognized and recognized itself as subject, concretizing the subjectivity in the cyberspace.
\end{abstract}

Key words: Cyberculture, identity, media visibility.

Resumen: Este artículo tiene por objetivo reflexionar sobre la identidad en comunidades virtuales de relación - sus construcciones simbólicas como referencia a la subjetividad del individuo y su relación con la alteridad en un ambiente de larga visibilidad, desde la constatación de que las redes telematicas componen nuevos procesos de subjetivación y el cyberespace garantiza nuevas formas de experimentación de las dimensiones del ser, del estar y del relacionarse. Para eso, propone un análisis del orkut como espacio discursivo de enunciación de uno mismo donde diversos procesos del signo están armados en la producción de $n$ espacio de habla, donde el individuo pueda ser reconocido y reconocer a uno mismo como sujeto, garantizando el aspecto real a su subjetividad en el cyberspace.

Palabras clave: Cibercultura, identidad, visibilidad de los médios de comunicación.

\section{Ser e estar no cyberspace: novos processos de subjetivação}

Entre o apagamento do sujeito na sociedade do espetáculo e a hiperespetacularização da imagem espectral nas plataformas de visibilidade ciberespacial, percebe-se o crescente trespassamento $^{1}$ da subjetividade pelas tecnologias de interface. Os processos de

\footnotetext{
${ }^{1}$ Mestranda do Programa de Estudos Pós-Graduados em Comunicação e Semiótica da Pontifícia Universidade Católica de São Paulo (PEPGCOS-PUC/SP) e bolsista CAPES. Sua pesquisa é orientada pelo Prof. Dr. Trivinho sob o título (provisório) de Cibercultura e subjetividade: uma investigação sobre a identidade em comunidades virtuais de relacionamento. E-mails: pubcintia@yahoo.com.br; cbello@cidadesp.edu.br.
} 
desreferencialização do real trazidos pela pós-modernidade ${ }^{2}$ intensificam-se com o presente fenômeno da cibercultura: novas tecnologias de (tele)comunicação criaram virtualidades que substituíram formas consagradas de se relacionar com o outro, de se perceber, ser e estar no mundo, inaugurando na esfera privada a produção desenfreada de simulacros na composição de imagens do "eu" próprias de uma cultura apresentacional", cujas dinâmicas de administração da impressão ${ }^{4}$ evidenciam-se na construção de perfis em comunidades virtuais de relacionamento como o Orkut.

A inscrição do "eu" em plataformas ciberculturais de alta visibilidade é uma das facetas da promiscuidade homem/máquina nos contextos de dromocratização ${ }^{5}$ e glocalização ${ }^{6}$ que dão legitimidade e naturalizam a visibilidade mediática como forma de existência. Para adentrar os ambientes virtuais e se imiscui nos fluxos informacionais, o sujeito transforma a si próprio em mensagem; sua experiência interativa não cabe mais na dicotomia emissor/receptor, tampouco é possível pensar cartesianamente os aspectos mensagem e canal se é o usuário, sedentário-nômade ${ }^{7}$, que se projeta, por meio do veículo comunicacional, em busca de conteúdo e todo o trajeto não é, senão, mensagem hipertextual "susceptível de acolher em seu interior os próprios usuários, por meio de seus espectros verbo-imagético-virtuais. Tal mistura virtual-heterogênea entre sujeito e objeto jamais foi ou será possível no processo de comunicação interpessoal e de massa” (TRIVINHO, 2001, p. 126).

Arrebatado pela velocidade catódica ${ }^{8}$, multiplicado pelos nós da rede, capilarizado e distribuído pelas interfaces, indexado pelas plataformas, vinculado a outros usuários nas comunidades virtuais, o sujeito experimenta novos processos de subjetivação na conjunção entre aceleração, excesso e produção de simulacros (BAUDRILLARD, 1991) na zona fronteiriça entre real presencial, virtualidade e hiper-real, o que expõe a crise das categorias modernas de identidade e sujeito e aprofunda a problemática da relação entre subjetividade, representação e simulação.

As práticas culturais relativas à construção e manutenção de corpos-sígnicos em comunidades virtuais (os chamados profiles ou perfis) apontam a emergência de uma nova forma de lidar com a identidade nos processos de espectralização da existência (DAL BELLO, 2007). A identidade deixa de ser considerada indivisível, centrada, singular e distintiva, relativa ao sujeito calcado no cogito cartesiano, para transformar-se em uma “celebração móvel” (HALL, 2004, p. 13), aparição performática e lúdica que não perde de vista a presença ululante de um público espectador também fluído, flexível, descomprometido e voyer. Nesse sentido, as comunidades virtuais não deixam de constituir cenários interessantes para os jogos sociais que se desenrolam na rede (SANTAELLA, 2003), conformando verdadeiros "laboratórios" no qual podem se desenvolver relacionamentos intensos ou evasivos, de intimidade e/ou superficialidade.

Concorda-se, pois, com a teoria de que o cyberspace, como media terciário ${ }^{9}$, tem um papel fundamental na formação e fomentação da cultura da virtualidade real, onde as aparências não apenas comunicam a experiência como constituem a própria experiência por meio de imagens e de som (BAITELLO Jr., 2001). Com a alteração radical da percepção de tempo e espaço, torna-se presente a ambivalência entre o eu e o anonimato, o sentimento de pertença e o desenraizamento, o local e o global - o que permite a vivência de novos aspectos existenciais, cognitivos e experienciais que resignificam as sensações de ser, pertencer e estar presente no mundo. É neste universo que se deseja refletir sobre os processos de espectralização da existência que engendram novas formas de lidar com a identidade, tomando como lócus de observação o Orkut. 


\title{
2. Orkut: plataforma hiperespetacular de representação e simulação
}

\begin{abstract}
Há, porém, uma família de palavras latinas na qual a imagem tem como referência a visão. Trata-se da palavra espetáculo, que vem dos verbos latinos specio e specto. Specio: ver, observar, olhar, perceber. Specto: ver, olhar, examinar, ver com reflexão, olhar, ajuizar, acautelar, esperar. Species é a forma visível da coisa real, sua essência ou sua verdade - na ciência da óptica, a species era estudada como imagem visual. Spectabilis é o visível.; speculum é o espelho; spectator, o que vê, observa, espectador; spectrum é aparição irreal, visão ilusória; speculare é ver com os olhos do espírito e spetaculum é a festa pública. Espetáculo pertence ao campo da visão. (CHAUí, 2006, p. 81-82).
\end{abstract}

Na ludicidade das práticas culturais associadas a ser/estar em comunidades virtuais de relacionamento, observa-se que o interator ${ }^{10}$, ou indivíduo teleinteragente ${ }^{11}$, se diverte em poder ver, perscrutar, espiar o outro "presente-ausente", configurado nas páginas que constituem o profile (ou perfil). Neste ponto, chama-se a atenção para a palavra 'especular', que como verbo comparece como sinônimo de ver, olhar atentamente, observar, vigiar e, como adjetivo, diz respeito ao que é diáfano ou relativo a espelho: não será exatamente isto do que trata o Orkut? Povoado por espectros (especulares, diáfanos) que se dão a ver e a especular nesta plataforma ciberespacial de alta visibilidade, o Orkut pode ser compreendido como um imenso "espelho interativo" que permite aos seus usuários construir e prestar manutenção à imagem que permanece mesmo quando não se está conectado, alternando “entre os estados de 'assujeitador' e de 'assujeitado', entre as condições de olhar e de imagem” (MACHADO, 2007, p. 235). Esta característica paradoxal acentua o desalinhamento e a hibridização entre sujeito, objeto e imagem, fazendo surgir, segundo Couchot (1993, p. 42), uma "nova ordem visual".

O sujeito não mais afronta o objeto em sua resistência de realidade, penetra-o em sua transparência virtual, como entra no próprio interior da imagem. O espaço muda: virtual, pode assumir todas as dimensões possíveis, até dimensões não inteiras, fractais. Mesmo o tempo flui diferente; ou antes, não flui mais de maneira inelutável; sua origem é permanente “reinicializável”: não fornece mais acontecimentos prontos, mas eventualidades. Impõe-se uma outra visão do mundo. (COUCHOT, 1993, p. 42).

À lógica da representação do real, relativa à sociedade do espetáculo ${ }^{12}$, segue-se, portanto, a lógica paradoxal da presentação do real hiperespetacularizado. Os corpos-sígnicos, elementos híbridos de texto, imagem e/ou som, atualizáveis em tempo real, não necessariamente remetem ao reflexo de uma alteridade física, constituindo uma nova fenomenologia da aparência: a da presentação na estética do desaparecimento trans-aparente (VIRILIO, 2005). A presentificação e celebrização do "eu" por meio de imagens virtuais trazem consigo a ilusão da eternidade quando, na verdade, testemunham a "dissipação do sujeito corporal, de sua identidade concreta” (CONTRERA, 2002, p. 54). Dado o descompromisso com uma realidade exterior, Silva (2007) se refere às imagens hiperespetacularizadas como imagens sem sombra, pura aparência, o que remete à mitologia das imagens (sombras) projetadas na caverna de Platão. “A primeira idéia da caverna é o isolamento, a separação de um dentro e um fora, um virtual e um atual, que definem a dicotomia da aparência e da essência” (MACHADO, 2007, p. 188). 
Da imagem sem sombra à imagem-sombra, resgata-se a natureza da imagem como duplo, reiterando o fascínio paradoxal pela celebrização do ordinário, pela presença na ausência, pela busca de uma essência do ser em sua imagem virtual, como se esta pudesse revelar uma qualidade que não se apresenta no presencial, uma qualidade de duplo.

O duplo é, efetivamente, essa imagem fundamental do homem, anterior à íntima consciência de si próprio, imagem reconhecida no reflexo ou na sombra, projetada no sonho, na alucinação, assim como na representação pintada ou esculpida, imagem fetichizada e magnificada nas crenças duma outra vida, nos cultos e nas religiões. [...] Cada um vive acompanhado do seu próprio duplo: não tanto uma cópia exata, mas mais, contudo, que um alter ego: ego alter, um eu-próprio outro. (MORIN, 1997, p. 44).

Para Morin (1997, p. 45), essa imagem fundamental de si mesmo corresponde a um eupróprio outro e superior, dotado de força mágica e mítica, "sinal primeiro e irrefutável da afirmação da individualidade humana... o esboço fantástico da construção do homem pelo homem”. De natureza projetável em imagens materiais, o duplo está no reflexo do espelho, na sombra ou nas imagens materiais que apresentam sua evidente exterioridade. "Qualquer signo, por sua própria natureza, na sua relação com aquilo que é por ele indicado ou que está nele representado, é um duplo" (SANTAELLA; NÖTH, 1999). Está, portanto, nos profiles das comunidades virtuais, com a diferença de que o sujeito pode revestir-se dessa imagem para mediatizar suas interações ciberculturais e atualizá-la conforme sua conveniência.

A despeito de se revelarem como imagens sem sombra, a construção dos profiles lida com a mitologização do sujeito, compreendendo sua auto-imagem, imagem mental tecnologicamente exteriorizada; por isso, não deixam de ser significativos para aqueles que os produziram para colonizar e se manifestar em ambientes como o Orkut, resultando em transferência ou implicação das qualidades dessa imagem mental no espectro virtual, ainda que, no ecrã, imagem e realidade não coincidam. Para Epstein (apud MORIN, 1997, p. 5758), "o que, realmente, nos perturba é essa profunda e contraditória sensação da nossa parecença e da nossa diferença. Surgimos, perante nós próprios, como exteriores e, ao mesmo tempo, idênticos ao que somos, eu e não-eu, ou seja, no fim de contas, ego alter”; transmutado em imagem, o sujeito percebe-se como uma "personalidade segunda, cujo aspecto pode perturbar a consciência ao ponto de esta perguntar a si própria: quem sou eu? Qual a minha verdadeira identidade?".

Chega-se à imagem como imagem de si mesma. Se, conforme Debord (2003, p. 9), “o espetáculo não é um conjunto de imagens, mas uma relação social entre pessoas mediatizada por imagens”, essa mediatização se radicaliza no hiperespetáculo: tudo é imagem, tudo é visibilidade $^{13}$, de tal forma que as relações sociais se dão para além da imagem que se tem do outro ou da projeção da imagem de si no outro: envolvem a "imagem de nós mesmos que desejamos transmitir" e a "imagem da imagem que idealizamos como imagem padrão" (SILVA, 2007, p. 37). E, se tudo é imagem, é tela, não há mais real a ser refletido. Daí Silva (2007, p. 33) referir-se ao hiperespetáculo não como um conjunto de imagens, mas como uma única imagem, irrefletida, apresentada sob a aparência da diversidade.

O hiperespetáculo é a vitória da imagem à la carte, pay-per-view ao alcance de todos contra a arbitrariedade de uma emissão de massa. No hiperespetáculo, como imaginário da fama, a visibilidade ofusca o seu negativo. O conteúdo pode ser preenchido com silicone. Afinal, estamos no pós-humano e nada impede que o saber seja uma prótese. O importante é fazer parte da tribo dos famosos, comungar os valores da celebridade e celebrar o valor simbólico. (SILVA, 2007, p. 37).

Da invasão de privacidade que se prestava a expor a intimidade de astros e estrelas com os quais se desejava parecer, chega-se à publicização gratuita do privado cotidiano, na ânsia de 
significar, com vistas a ser reconhecidamente alguém - comportamento que Severiano (2001, p. 35) computará ao sujeito pós-moderno que, egocentrado, hedonista e "fascinado pelo espetáculo das novas tecnologias informatizadas", "persegue exaustivamente a fama e a celebridade como um direito natural" e "apenas necessita do outro como instrumento de confirmação e admiração do próprio eu”.

A produção de conteúdo no Orkut implica a seleção de simulacros ${ }^{14}$ de representação e/ou de simulação. Na representação, relativa ao domínio da aparência, lida-se com o simulacro no sentido platônico, sempre insuficiente para estabelecer um padrão de equivalência com o original que substitui; é cópia secundária que guarda alguma verossimilhança com o real, e por meio da qual o real pode ser reconhecido; para Platão (apud WOLFF, 2005, p. 21), não convém que a imagem reproduza "todos os traços do objeto imitado" para que ambos não se confundam: enquanto a realidade é única, as imagens que se possam fazer dela são múltiplas e fadadas à reprodução mecanizada. Imitação do verdadeiro ser, não contém "a realidade daquilo que representa”.

Em suma, a imagem é um ser menor do que aquele que ela representa, é um falso ser, simples imitação da aparência, é múltipla em lugar de uma. De maneira que a imagem é a representação reprodutível de uma coisa ausente única, que lhe empresta alguns traços aparentes e visíveis. (WOLFF, 2005, p. 23).

Na simulação, o simulacro se apresenta no sentido epicuriano: não é cópia, não guarda relação com um referente distante, externo a si. Por essa razão, "oblitera a distinção verdadeiro/falso, real/imaginário, verdade/mentira”, transformando-se em seu próprio valor de uso na simultaneidade do presente momento (SFEZ, 1994, p. 274). Por ser mais que suficiente, é mais que real, presidindo o esvaziamento da realidade em prol de uma hiper-realidade. Suprime-se, assim,

\begin{abstract}
a imemorial maldição que acoplava imagem e imitação. Ela estava acorrentada ao seu estatuto especular de reflexo, decalque ou engodo, na melhor hipótese substituto e, na pior, embuste, mas sempre ilusão. Seria, então, o fim do milenar processo das sombras, a reabilitação do olhar no campo do saber platônico. Com a concepção assistida por computador, a imagem produzida deixa de ser cópia secundária de um objeto anterior: é o inverso. Contornando a oposição entre ser e parecer, semelhante e real, a imagem graficamente computadorizada já não tem de imitar um real exterior, já que é o produto real que deverá imitá-la para existir. Toda relação ontológica que, desde os gregos, desvalorizava e, ao mesmo tempo, dramatizava nosso diálogo com as aparências se encontra invertida. (DEBRAY, 1994, p. 277).
\end{abstract}

A simulação apresenta-se, portanto, como o êxtase do real, "essa qualidade própria a todos os corpos que giram sobre si mesmos até a perda de consciência e que resplandecem então em suas formas puras e vazias” (BAUDRILLARD, 1996, p. 9). É a auto-referência presente no simulacro que o torna vazio de referências exteriores, ao passo que também lhe permite ser mais verdadeiro que o verdadeiro, conferindo ao sistema integrado dos circuitos uma vertiginosa sensação de verdade.

\title{
3. Espectralização da identidade: entre o reflexo e a sombra
}

Com base no entendimento dos conceitos de representação e simulação, propõe-se um modelo de classificação para análise de profiles que estabelece dois parâmetros: o primeiro calca-se na representação e conforma um espectro virtual que revela o duplo como reflexo; o segundo, relativo à simulação, apresenta a natureza do duplo como sombra. 
Todas as modalidades de signos, inclusive as imagens, têm o propósito e a função de representar e interpretar a realidade, mas, ao fazê-lo, inevitavelmente interpõem-se entre homem e mundo. Assim como os espelhos, ao mesmo tempo que os signos refletem a realidade, também a refratam, quer dizer, ao refletir, transformam, transfiguram e, numa certa medida, até mesmo deformam o que é por eles refletido. (SANTAELLA; NÖTH, 1999, p. 131).

Faz-se necessário, portanto, observar as características e os desdobramentos de cada parâmetro.

\subsection{A constituição do espectro virtual como reflexo}

No Orkut, mediante a tarefa de produzir um perfil que dê conta de representar o seu "eu", o sujeito se depara com uma longa enquete a ser respondida, dividida em cinco categorias: informações de caráter geral ${ }^{15}$; social; profissional, pessoal e contato ${ }^{16}$. Não há a necessidade de responder a todos os tópicos para fazer uso do ambiente virtual; além disso, o usuário pode definir o nível de restrição ${ }^{17}$ a algumas informações preenchidas, inclusive álbum de fotos, vídeos e scrapbook (página de recados). Costuma-se fazer upload de uma foto para identificação pessoal (chamada "foto do perfil", o equivalente à fotografia em um documento de identidade). Essa imagem, seguida do nome, aparece em todos os perfis de usuários vinculados como amigos e também é reproduzida ao lado de recados e depoimentos deixados em outros profiles; em ambos os casos, funciona como um hiperlink que leva diretamente ao perfil do sujeito.

O conteúdo de um profile também é formado pelos depoimentos e recados deixados por outros usuários, e pelas imagens hiperlinkadas dos amigos e das comunidades às quais se vinculou. Observa-se que o excesso expresso na quantidade de amigos, scraps, fotos e vídeos, bem como nos índices de popularidade (fãs, confiável, legal e sexy), servem para referenciar e celebrizar o sujeito ali constituído. Há, portanto, uma larga produção sígnica de si que, exatamente por perseguir uma imagem ideal, exige constantes atualizações e mostra-se sempre insuficiente. Mesmo a filiação a diversas comunidades constitui um discurso de autoreferência.

O que constitui a página inicial de um profile? Além dos índices de popularidade e a quantidade de amigos e comunidades às quais se está associado, pode-se observar a imagem do perfil, os dados de caráter social e os links de acesso às outras páginas do profile (ver figura 1). 


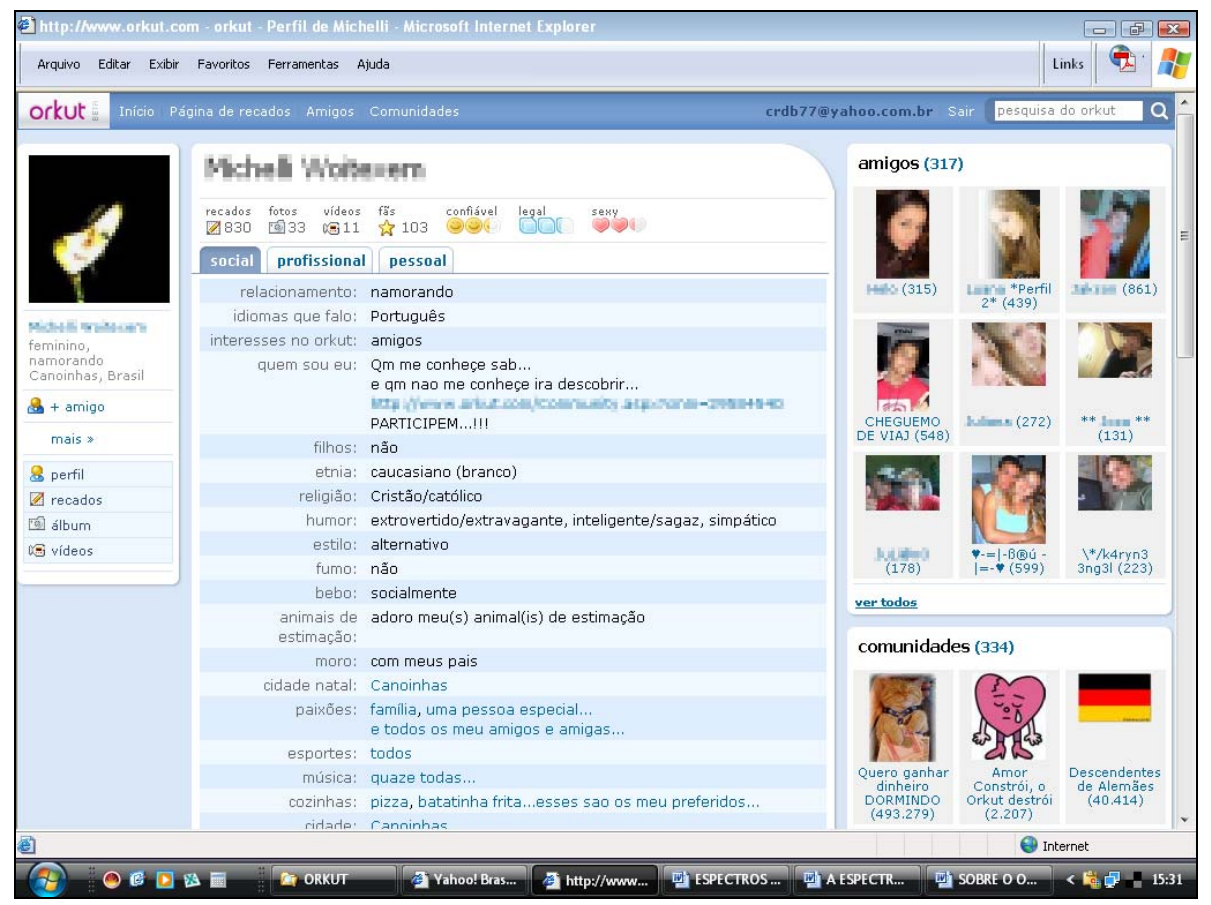

Figura 1. Página inicial de um perfil do Orkut.

Este espectro virtual apresenta sua natureza de duplo como reflexo ${ }^{18}$, mas reflexo de um "espelho interativo" que permite a melhoria de alguns aspectos de acordo com a impressão que se deseja passar. O usuário não perde de vista o fato de que está em um ambiente de alta visibilidade e por isso, apesar dos indícios-icônicos ${ }^{19}$ que se reportam à corporeidade física de identidade publicamente conhecida, procura publicizar a melhor imagem de si. Nota-se, em grande parte dos perfis, que esta imagem é a imagem especular (o duplo-reflexo): como pode ser observado na figura 2, muitos usuários fazem uso de espelhos e imagens especulares para compor a imagem principal do seu perfil.

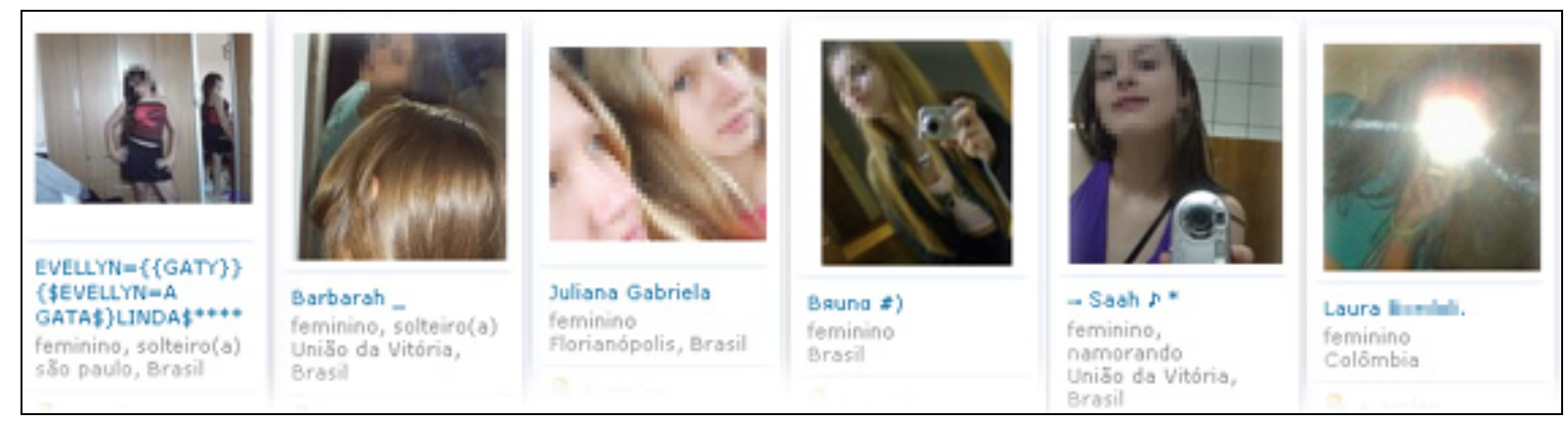

Figura 2. Seleção de fotos de perfis que utilizam a imagem especular como recurso de representação.

\subsection{A constituição do espectro virtual como sombra}

Profiles construídos sem qualquer relação com a categoria da representação constituem perfis fakes, simulacros (epicurianos) puros, forjados para que se possa usufruir o Orkut sem que a atuação possa acarretar danos à imagem pessoal do sujeito por traz da "máscara”. Não deixam de constituir emanações de uma subjetividade concreta que opera de um bunker ${ }^{20}$ glocalizado, embora esta permaneça anônima. 
Como fantasmagorias, perambulam pelas comunidades e assombram os demais com o seu anonimato e o seu voyerismo, chegando ao limiar do terrorismo virtual (de alcance psicológico). Na perpetração de perversidades ou outras ações passíveis de julgamento ético e/ou deontológico, o perfil fake constitui aquele com o qual não se deseja publicamente parecer. Neste sentido, muito pouco ou quase nada constitui conteúdo do profile (como pode ser observado na figura 3). Liberto da existência de uma identidade real, correspondente a uma entidade corpórea, física, cuja imagem (social) precise ser preservada, este espectro virtual apresenta sua natureza de duplo como sombra ${ }^{21}$.

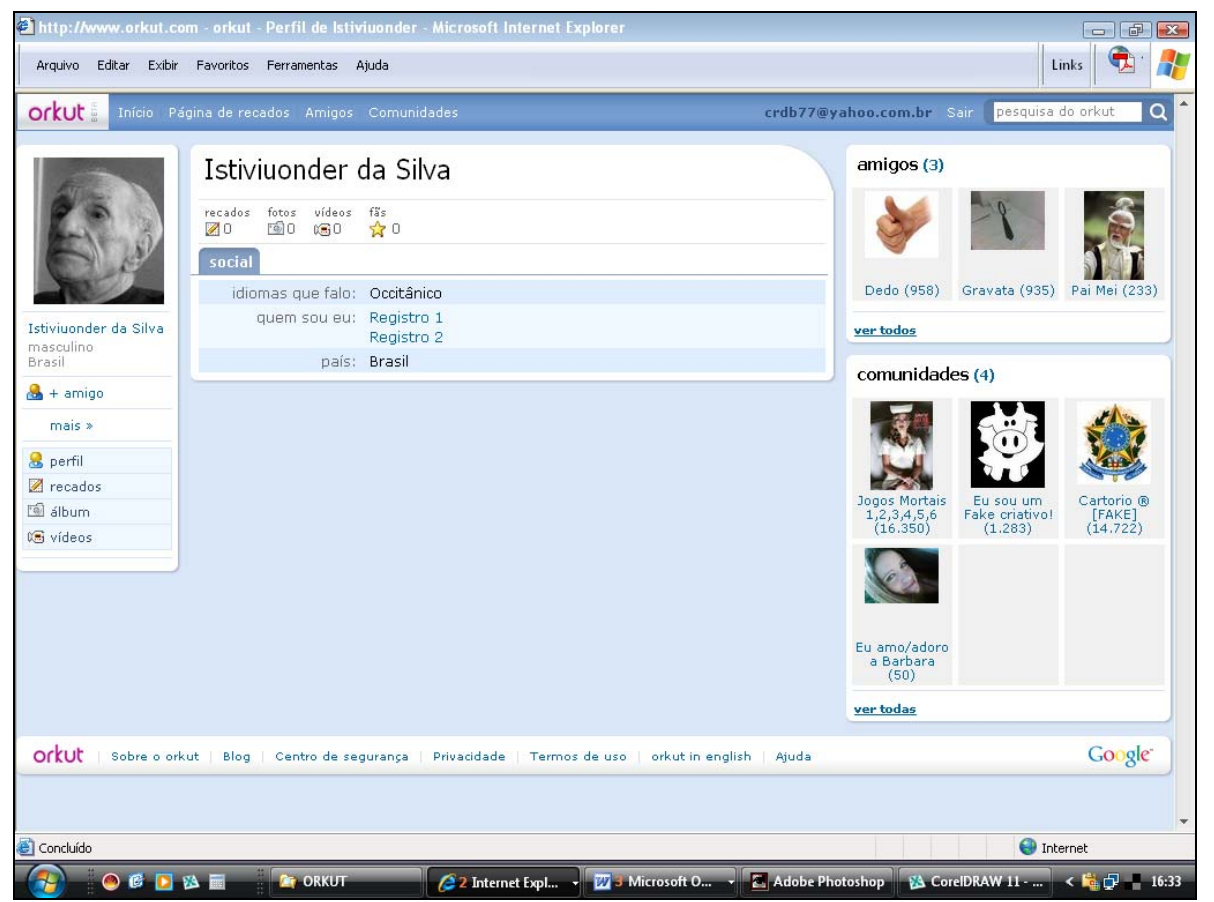

Figura 3. Página inicial de um perfil fake do Orkut.

Em sua dimensão lúdica, identidades espectrais dessa natureza permitem que sejam experimentadas outras possibilidades de ser e se relacionar, conduzindo o indivíduo "a uma reflexão acerca de si mesmo" (SFEZ, 1994, p. 247) na construção de personas para "interação com o outro especular, isto é, outras personas do ciberespaço” (SANTAELLA, 2003, p. 214). A encenação de um papel pode ser levada tão a sério que o sujeito passa a atuar literalmente como a celebridade ou a personagem que montou para si. Busca constituir uma família (outros fakes aos quais se associa para construir uma relação familiar) e passa a freqüentar comunidades como shoppings, hotéis, bancos e festas fakes, providenciando inclusive um registro de nascimento ${ }^{22}$. Simula-se viver em um mundo à parte do mundo presencial: "nas ilusões ou ficção que engendram, o midiático e o virtual demandam outros véus, peles, personas, máscaras que, multiplicadas, podem atribuir uma realidade fantasmática ou espectral aos sujeitos” (SODRÉ, 2002, p. 153). Nesse sentido, o duplo corresponde às metáforas da máscara ou da fantasia, mas a identidade (relativa à alteridade física no comando do perfil) continua obscurecida, na "sombra". 


\subsection{Considerações sobre identidade, corpos-sígnicos e hiperespetacularização}

Para Flusser (1985, p. 15), os signos exercem tanto a função de mapas quanto de biombos: por um lado, remetem à realidade; por outro, não mostram todos os traços do real, ocultando-o em parte. Essa constatação ilustra, ou denuncia, o fato de que o corpo-sígnico é uma realidade em si que reflete ou obscurece uma realidade fora dele.

Kamper (2006) afirma que os homens de hoje vivem nas imagens do mundo, de si próprios e dos outros homens - uma permanência imaginária que conduz à condição de uma vida morta. O enredamento mental e emocional no turbilhão de imagens do Orkut, possível graças aos corpos-sígnicos projetados sobre os parâmetros da representação ou da simulação, esconde "a real imobilidade corpórea” (SODRÉ, 2002, p. 162) que resulta na crescente perda do sentido da propriocepção ${ }^{23}$. Para Kamper (2006, p. 11), já que às imagens se prendem os desejos de imortalidade, fazer uma imagem do corpo humano "significa alinhá-lo na falange dos mortosvivos, dos espectros e fantasmas".

A ilusão criada pelas imagens é a ilusão do fantasma ou do ícone. Ela não consiste de forma alguma em atribuir às imagens aquilo que se atribui à própria realidade. É até exatamente o contrário: ela consiste em atribuir à própria realidade o poder que é das imagens, o poder de representar. A ilusão imaginária consiste em crer que a realidade tem o poder de sua própria representação, em atribuir à realidade ausente representada pela imagem o poder de se apresentar ela mesma em imagem. (WOLF, 2005, p. 38).

A publicização, encenação e hiperespetacularização de identidades, neste contexto, levam à crescente espectralização da existência: a lógica do hiperespetáculo é a da apropriação pelo olhar, e nela, “deixar-se olhar significa deixar-se apropriar” (BAITELLO Jr., 2005, p. 20), o que incide na indexação sígnica ${ }^{24}$ de tudo o que constitui a pele dos espectros. Eis a lógica coercitiva do "apareSer".

\section{Referências}

BAITELLO Jr., Norval. O tempo lento e o espaço nulo: mídia primária, secundária e terciária. In: FAUSTO Neto, Antônio et al. (Org.). Interação e sentidos no ciberespaço e na sociedade. Porto Alegre: EDIPUCRS, 2001. (Coleção Comunicação, 11. Compôs; v.2).

2005.

A era da iconofagia: ensaios de comunicação e cultura. São Paulo: Hackers Editores,

Las capilaridades de la comunicación. In: SARTORI, R.B. (Ed.), MUÑOZ, B.O. (Ed.) e VALENZUELA, V. H. (Ed.). Diálogos culturales. São Paulo: Annablume, 2007. BAUDRILLARD, Jean. Simulacros e simulação. São Paulo: Relógio D’ Água, 1991.

. As estratégias fatais. Rio de Janeiro: Rocco, 1996.

CHAUÍ, Marilena. Simulacro e poder: uma análise da mídia. São Paulo: Fundação Perseu Abramo, 2006.

CONTRERA, Malena Segura. Mídia e pânico: saturação da informação, violência e crise cultural na mídia. São Paulo: Annablume: Fapesp, 2002.

COUCHOT, Edmond. Da representação à simulação. In: PARENTE, André (Org.). Imagemmáquina: a era das tecnologias do virtual. São Paulo: Ed. 34, 1993.

DAL BELLO, Cíntia. A espectralização da existência: indexação sígnica em comunidades virtuais de relacionamento. In: IX SEMINÁRIO INTERNACIONAL DA COMUNICAÇÃO, 9., 2007, Porto 
Alegre. Simulacros e (dis)simulações na sociedade hiperespetacular. Porto Alegre: PUCRS, 2007. Pg. $47-64$.

Disponível em: <http://www.pucrs.br/eventos/sicom/textos/gt03.pdf>. Acesso em: 10 nov. 2007.

DEBORD, Guy. Sociedade do espetáculo. 2003. Disponível em:

<http://www.cisc.org.br/portal/biblioteca/socespetaculo.pdf>. Acesso em: 10 ago. 2007.

DEBRAY, Régis. Vida e morte da imagem. Petrópolis: Vozes, 1994.

FLUSSER, Vilém. Filosofia da caixa preta: ensaios para uma futura filosofia da fotografia. São Paulo: Hucitec, 1985.

FREIRE Filho, João. Sociedade do espetáculo à sociedade da interatividade? In: GUTFREIND, Cristiane Freitas; SILVA, Juremir Machado da. Guy Debord: antes e depois do espetáculo. Porto Alegre: EDPUCRS, 2007.

HALL, Stuart. A identidade cultural na pós-modernidade. 9. ed. Rio de Janeiro: DP\&A, 2004.

JAMESON, Fredric. Pós-modernismo: a lógica cultural do capitalismo tardio. São Paulo: Ática, 1997.

JUNG, Carl Gustav. Memórias, sonhos e reflexões. Rio de Janeiro: Nova Fronteira, 1989.

KAMPER, Dietmar. Imagem. 2006.

Disponível em: <http://www.cisc.org.br/portal/biblioteca/imagemkamper.pdf>.

Acesso em: 10 set. 2006.

MACHADO, Arlindo. Sujeito na tela: modos de enunciação no cinema e no ciberespaço. São Paulo: Paulus, 2007.

MORIN, Edgar. O cinema ou o homem imaginário. Tradução: António-Pedro Vasconcelos. São Paulo: Relógio d’Água Editores, 1997.

RÜDIGER, Francisco. Guy Debord e a teoria crítica: trajetória, atualidade e perspectivas. In: GUTFREIND, Cristiane Freitas; SILVA, Juremir Machado da. Guy Debord: antes e depois do espetáculo. Porto Alegre: EDPUCRS, 2007.

SANTAELLA, Lucia; NÖTH, Winfried. Imagem: cognição, semiótica, mídia. São Paulo: Iluminuras, 1999.

SANTAELLA, Lucia. Culturas e artes do pós-humano. São Paulo: Paulus, 2003.

SILVA, Juremir Machado da. Depois do espetáculo (reflexões sobre a tese 4 de Guy Debord). In: GUTFREIND, Cristiane Freitas; SILVA, Juremir Machado da. Guy Debord: antes e depois do espetáculo. Porto Alegre: EDPUCRS, 2007.

SEVERIANO, Maria de Fátima Vieira. Narcisismo e Publicidade: uma análise psicossocial dos ideais de consumo na contemporaneidade. São Paulo: Annablume, 2001.

SFEZ, Lucien. Crítica da comunicação. São Paulo: Loyola, 1994.

SODRÉ, Muniz. Antropológica do espelho: uma teoria da comunicação linear e em rede. Petrópolis: Vozes, 2002.

TRIVINHO, Eugênio. O mal-estar da teoria: a condição da crítica na sociedade tecnológica atual. Rio de Janeiro: Quartet, 2001.

A dromocracia cibercultural: lógica da vida humana na civilização mediática avançada.

São Paulo: Paulus, 2007.

VIRILIO, Paul. Cibermundo: a política do pior. Lisboa: Teorema, 2000.

O espaço crítico: e as perspectivas do tempo real. São Paulo: Ed. 34, 2005.

WOLFF, Francis. Por trás do espetáculo: o poder das imagens. In: NOVAES, Adauto (Org.). Muito além do espetáculo. São Paulo: Senac, 2005.

\footnotetext{
${ }^{1}$ Cf. Couchot (1993) e Machado (2007).

${ }^{2}$ Para Jameson (1997), as características da pós-modernidade se reproduzem no sujeito pós-moderno, estruturalmente descentrado, fragmentado, marcado pela superficialidade e pela relatividade.

${ }^{3}$ Cf. Silverstone (2002).

${ }^{4}$ Cf. Costa (2002).
} 
${ }^{5}$ Manifestos no engendramento e sistematização da violência pelo tempo real (VIRILIO, 2000, 2005; TRIVINHO, 2001, 2007).

${ }^{6}$ O termo glocal é tratado como categoria crítica na obra de Trivinho (2001, 2007). Compreendido como a "contribuição antropológica mais autêntica da civilização mediática ao âmbito socialhistórico” (TRIVINHO, 2007, p. 258), sinaliza uma acentuada fissura entre a dimensão dos lugares, onde se assenta a experiência corporal, concreta, física; e a dimensão comunicacional dos não-lugares, povoada de entidades humano-sígnicas, espectrais.

${ }^{7}$ Cf. Trivinho (2001). Neste sentido, Baitello Jr. (2007) refere-se ao nomadismo virtual ou neonomadismo.

${ }^{8}$ Referência utilizada por Virilio (2000, 2005) para aludir ao processamento das informações (em tela) na velocidade da luz, também denominado de "tempo real".

${ }^{9} \mathrm{O}$ conceito de media terciário relaciona-se com os meios eletrônicos de comunicação e apresenta como principais características a anulação do espaço, a aceleração do tempo, a mediatização da oralidade, a conservação da presença e a exigência de disponibilidade tecnológica tanto para o emissor quanto para o receptor. A classificação é de Pross (apud BAITELLO Jr., 2001, p. 236-237).

${ }^{10}$ Para Machado (2007, p. 144), o interator é aquele "receptor ativo e imerso" cuja ação participativa está para além de "expressões como usuário, espectador e receptor".

${ }^{11}$ Trivinho (2001, p. 124-127) funde nesta expressão as categorias analíticas de emissor, receptor e mensagem, dado que para adentrar, navegar, existir e interagir no cyberspace o usuário precisa, necessariamente, transformar-se em conjunto de signos verbo-imagético-sonoros.

${ }^{12}$ O conceito, como tratado por Debord (2003), é bastante complexo. Para Freire Filho (2007, p. 63), refere-se ao rebaixamento dos sujeitos "ao mero papel de espectadores, de indivíduos isolados ('geralmente no âmbito da célula familar')", impelindo-os a se relacionarem com o mundo por meio de imagens como uma estratégia produzida "pelos agentes do mercado e do estado - bens, serviços e representações que nos matem entretidos, ocupados, sem nos tornar efetivamente ativos”. Para Rüdiger (2007), embora Debord tenha saído dos anos 1970 "com uma teoria da conspiração, em lugar de uma teoria crítica" (p. 163), a atualidade do texto "encontra-se sobretudo em seu alerta, de modo algum original, para o fato, agora todavia ainda mais claro, de que o capitalismo se expande e cria ressonância entre seus sujeitos pela criação e exploração mercantil de imagens objetivas” (p. 170).

${ }^{13}$ Cabe ressaltar que se toma o conceito de "visibilidade" de forma ampla, relativo à faculdade de se fazer visível (perceptível) ao outro, por meio de imagens visuais ou sonoras (BAITELLO Jr., 2005).

${ }^{14}$ Chauí (2006) vem recordar que simulacrum é oriundo da palavra latina similis, de onde derivam similitudo (semelhança, analogia, comparação) e o verbo simulare (representar exatamente, copiar, tomar a aparência de, fingir, simular), do que depreende-se que simulacro relaciona-se com ambos os conceitos.

${ }^{15}$ Correspondente à página de cadastro no ambiente virtual, requer o preenchimento dos seguintes tópicos: nome, sobrenome, sexo, estado civil, data de nascimento, cidade, estado e país de origem, idiomas que fala, escolaridade, profissão, interesses no Orkut.

${ }^{16}$ São solicitados os seguintes dados: e-mail principal e indicação de até três e-mails secundários, instant messenger (IM) do Google Talk, telefone residencial, celular, SMS, endereço completo (até duas indicações).

${ }^{17}$ Para as informações que compõe o perfil, existem quatro níveis de restrição: "só eu”, "amigos”, "amigos de amigos”, "todos”. Para o álbum e o scrapbook, são apenas dois: “amigos” ou "todos”.

${ }^{18}$ A temática do narcisismo será aprofundada em trabalho posterior; aqui, fica o registro de que se vislumbra nesse processo de construção sígnica a motivação de caráter narcisística.

${ }^{19}$ Santaella e Nöth (1999, p. 107) fazem referência à capacidade que a fotografia tem de apresentar-se como ícone e índice ao mesmo tempo: "por um lado, ela reproduz a realidade através de (aparente) semelhança; por outro, ela tem uma relação causal com a realidade devido às leis da ótica”. Neste sentido, a imagem é compreendida como vestígio, testemunha e até mesmo uma emanação do objeto. 
${ }^{20}$ Embora o termo faça referência direta à concepção de "microcinturão tecnológico" (TRIVINHO, 2007, p. 310), a atuação na rede por meio do anonimato revela a crescente bunkerização da mentalidade e do imaginário, concernente a "um ethos específico, no sentido etimológico: forma de estar e de agir no mundo, em compatibilidade com as necessidades de reprodução social-histórica da cibercultura" (TRIVINHO, 2007, p. 312).

${ }^{21}$ Para Jung (1989, p. 359), a sombra corresponde à parte inferior da personalidade, recalcada e freqüentemente carregada de culpabilidade (embora não seja, necessariamente, formada por conteúdos repreensíveis). Relativamente autônoma, apresenta "tendências opostas às do consciente". Engloba todo o aspecto histórico do inconsciente.

${ }^{22}$ Referência à comunidade "Cartório Fake".

${ }^{23}$ Segundo Baitello Jr. (2005, p. 42), “a propriocepção é o sentido do próprio corpo. Descoberta por Sherrington na década de 1890, constitui o outro sentido, além de visão, olfato, tato, paladar e audição”.

${ }^{24} \mathrm{O}$ fenômeno do gerenciamento cibercultural a partir da indexação sígnica (DAL BELLO, 2007) foi abordado em trabalho anterior. 